\title{
Combination of metformin and cold atmospheric plasma induces glioma cell death to associate with c-Fos
}

\author{
Fan YANG ${ }^{1,2}$, Yuanshuai ZHOU ${ }^{2}$, Huidan $\mathrm{YU}^{3}$, Jiao YANG ${ }^{2}$, Cheng ZHU ${ }^{4,5}$, Nafees AHMAD ${ }^{6}$, Xingjun MENG ${ }^{2}$, Rongchuan ZHAO ${ }^{2,4}$, Jie ZHUANG ${ }^{4,5, *}$, \\ Minxuan SUN ${ }^{2,4, *}$ \\ ${ }^{1}$ School of Life Sciences, Shanghai University, Shanghai, China; ${ }^{2}$ Jiangsu Key Lab of Medical Optics, Suzhou Institute of Biomedical Engineering \\ and Technology, Chinese Academy of Sciences, Suzhou, Jiangsu, China; ${ }^{3}$ School of Life Science and Technology, Changchun University of Science \\ and Technology, Changchun, Jilin, China; ${ }^{4}$ University of Science and Technology of China, Hefei, Anhui, China; ${ }^{5}$ Suzhou Institute of Biomedical \\ Engineering and Technology, Chinese Academy of Sciences, Suzhou, Jiangsu, China; ' Institute of Biomedical and Genetic Engineering, Islam- \\ abad, Pakistan
}

${ }^{*}$ Correspondence: jzhuang@sibet.ac.cn; minxuan.sun@sibet.ac.cn

Received March 25, 2020 / Accepted August 6, 2020

\begin{abstract}
Glioma is the most common type of brain cancer. Chemotherapy combination with surgery and radiotherapy is a standard treatment for patients. Although there are many advances in glioma therapy, the prognosis of glioma patients has not significantly been improved over the past decades. Hence, there is still an urgent need to develop a new therapy to treat glioma. Cell viability was assessed by CellTiter Blue assay; flow cytometry (FCM) was used for detecting cell apoptosis; ROS detection was detected by ROS Assay; $\mathrm{H} 2 \mathrm{O} 2$ detection was performed by hydrogen peroxide detection kits; real-time PCR and WB were used to determine gene expression. Using the glioma cell line U251 and U87, we investigated a possible combination inhibitory effect includes metformin and cold atmospheric plasma (CAP). The combination treatment showed a synergistic inhibitory effect on cell viability, significantly inducing cell apoptosis. Furthermore, we also found $\mathrm{H} 2 \mathrm{O} 2$ produced by CAP has an important role in the synergistic inhibitory effect, eliminating $\mathrm{H} 2 \mathrm{O} 2$ with catalase reversed the synergistic inhibitory effect. In addition, the transcript and protein levels of c-FOS were robustly increased after co-treated with metformin and CAP. Taken together, we propose that pre-treatment of glioma cells with metformin sensitize tumor cells to CAP, which may serve as a potential therapeutic strategy for glioma.
\end{abstract}

Key words: metformin, cold atmospheric plasma, glioma, synergistic inhibitory effect

Glioma is the most common primary brain tumor and glioblastoma (GBM) is the most malignant form of glioma with 5-year survival rates of $5 \%$ [1]. The incidence of the tumor in China is 1-4/100,000 [2]. The 2016 World Health Organization classification of central nervous system tumors separates glioma into circumscribed gliomas (WHO grade I) and diffusely infiltrating gliomas (WHO grades II-IV) based on their pattern of histological feature and genetic mutant [3]. Chemotherapy combined with surgery and radiotherapy is a standard clinical treatment for patients [4]. Temozolomide (TMZ), is the first-line treatment for glioblastoma multiforme and second-line treatment for astrocytoma. TMZ is an alkylating agent that attenuates glioma through alkylating guanine at the $\mathrm{O}^{6}$ position along with additional contributions at the $\mathrm{N}^{3}$ and $\mathrm{N}^{7}$ positions of adenine [5]. However, accumulating evidence points toward resistance of GBM patients or no response to TMZ-based chemotherapy. Hence, there is still an urgent need to develop a new therapy to treat glioma.
Plasma is the fourth state of matter after solid, liquid, and gas, formed under high-temperature. The plasma with a room temperature called cold atmospheric plasma (CAP). CAP is composed of multiple reactive free groups including reactive oxygen species (ROS, such as hydroxyl radical $\left(\mathrm{OH}^{-}\right)$, hydrogen peroxide $\left(\mathrm{H}_{2} \mathrm{O}_{2}\right)$, ozone $\left(\mathrm{O}_{3}\right)$, and superoxide $\left(\mathrm{O}_{2}^{-}\right)$) and reactive nitrogen species (RNS, such as nitric oxide $\left(\mathrm{NO}^{-}\right)$and anionic $\left(\mathrm{OONO}^{-}\right)$and protonated $(\mathrm{ONOOH})$ forms of peroxynitrite) [6]. In the past decades, CAP and CAP activated medium (CAM) exhibit a broadspectrum anti-tumor effect in vitro and in vivo [7-12]. CAP or CAM has been used in combination with some agents to attenuate tumors. Adachi et al. confirmed that histone deacetylase (HDAC) inhibitors have the potential to enhance the susceptibility of A549 to CAM [12]. Pre-sensitization of breast cancer cells with HSP90 inhibitor (PU-H71) followed by the treatment with CAP, synergistically induce cell death [11]. TMZ-resistant GBM cells restore sensibility after treat- 
ment of CAP [13]. This year, FDA approved a clinical trial of cold plasma "scalpel" for cancer treatment. Thus, CAP has the potential to become an auxiliary physical therapy for chemotherapy.

Metformin (Met) is the most important drug for patients with type 2 diabetes mellitus (T2DM) [14]. metformin inhibits electron transport chain (ETC) and elevates AMP/ ATP ratio, resulting in AMP-activated protein kinase (AMPK) activation and the mechanistic target of rapamycin complex 1 (mTORC1) inhibition, finally change cell progress [15]. In recent years, metformin has been used to inhibit the tumor cells proliferation directly or to increase the sensitivity of multiple tumors to chemotherapeutic agents [16-22]. In this study, we found that Met had a weak toxic effect on U251, U87 cell lines even in a high concentration of Met $(16 \mathrm{mM})$, while CAP had an obviously dose-dependent toxic effect. In addition, pre-treated glioma cells with Met significantly enhanced the sensitivity of the cells to CAP. The combination therapy remarkably induced cell death. In a further study, upregulation of c-fos was observed in combination therapy, however, the role of $\mathrm{c}$-fos in synergistic effect needs to be further explored. Our findings suggest that CAP combined with Met may serve as a potential therapy for glioma patients.

\section{Materials and methods}

Cell culture and plasma treatment. U251 and U87 cell lines were purchased from the Cell Bank of the Chinese Academy of Sciences (Shanghai, China). Cells were grown in high glucose Dulbecco's minimum essential media (DMEM, HyClone) supplemented with $10 \%$ fetal calf serum (FCS) and 100 units/ml penicillin, $100 \mathrm{mg} / \mathrm{ml}$ streptomycin (Gibco). Cells were cultured at $37^{\circ} \mathrm{C}$ in an incubator (Thermo Fisher Scientific) containing $5 \% \mathrm{CO}_{2}$. In total, U251 cells and U87 cells were seeded for $12 \mathrm{~h}$ in 96-well plates and then used in experiments. Cells were treated with the indicated concentrations of metformin. $\mathrm{dd}_{2} \mathrm{O}$ was used as vehicle control. The atmospheric pressure argon plasma jet kINPen 11 served as a reactive species-generating source and was operated at a frequency of $1 \mathrm{MHz}$, a voltage of $3 \mathrm{kV}$ with a feed gas flux of 4 standard liters/min. The distance between the CAP source and the bottom of the plates was fixed at $3 \mathrm{~cm}$ in height. Cells were exposed to CAP for the indicated times.

Cell viability. For the Met or CAP treatment only, cells were treated with indicated concentrations or exposure times and further incubated for $24 \mathrm{~h}$ or $48 \mathrm{~h}$. For the combi- nation group, cells were incubated with Met for $12 \mathrm{~h}$, and further incubated for $12 \mathrm{~h}$ after exposure to CAP. Then fresh complete DMEM $100 \mu$ with $20 \mu$ Cell Titer-Blue Cell Viability Assay reagents (Promega) was added. The plate was incubated for $4 \mathrm{~h}$ at $37^{\circ} \mathrm{C}$, and fluorescence was measured in a multimode plate reader (Thermo Fisher) at $\lambda_{\text {ex }} 560 \mathrm{~nm}$ and $\lambda_{\mathrm{em}} 590 \mathrm{~nm}$. Cell viability was shown as the percentage of untreated control.

Flow cytometry. Cell apoptosis analysis was carried out by flow cytometry (BD). Cells were seeded in 12-well plates for $12 \mathrm{~h}$ and pre-treated with metformin $(16 \mathrm{mM})$ for another $12 \mathrm{~h}$. Then cells were exposed to CAP (30 s) and incubated for $12 \mathrm{~h}$. After treatment, the apoptosis ratio was analyzed using an eBioscience Annexin V Apoptosis Detection Kit APC (Thermo Fisher) according to the manufacturer's protocol.

ROS detection. $30 \mathrm{~s}$ after CAP treatment, the intracellular ROS and the $\mathrm{H}_{2} \mathrm{O}_{2}$ concentration in the medium were detected according to the manufacturer's protocol. Briefly, for the ROS detection, DCFH-DA (ROS Assay Kit, Beyotime) was diluted with a serum-free medium at 1:1000 to a final concentration of $10 \mu \mathrm{M}$. Afterward, the culture medium was removed and the appropriate volume of diluted DCFH-DA was added. Incubation was made in a $37^{\circ} \mathrm{C}$ cell incubator for 20 minutes. The cells were washed three times with a serumfree cell culture medium to sufficiently remove DCFH-DA that did not enter the cells. The fluorescence was observed through the Olympus fluorescence microscopy. For the $\mathrm{H}_{2} \mathrm{O}_{2}$ detection, hydrogen peroxide detection reagent (Beyotime) was thawed on ice or an ice-water bath. $50 \mu$ of treated culture medium was added to the detection well, and $100 \mu \mathrm{l}$ of the hydrogen peroxide detection reagent to each well. Gently shake or beat to mix. Left at room temperature $\left(15-30^{\circ} \mathrm{C}\right)$ for 30 minutes, and then measured A560 immediately on a multimode plate reader (LEICA).

qRT-PCR. After treatment (described in Flow cytometry), cells were washed once with ice-cold PBS and total RNA was extracted from cells with $0.2 \mathrm{ml}$ of RNAiso Plus reagent (TaKaRa). The preparation of cDNA and reverse transcriptional-polymerase chain reaction (RT-PCR) were performed according to the manufacturer's protocol. Changes in mRNA expression were measured by using the SYBR Green Realtime PCR Master Mix gene expression assay (TOYOBO). Real-time PCR was performed on Applied Biosystems 7500 Real-time System (Applied Biosystems) using primers shown in Table 1.

Western blotting. Cells were washed twice using ice-cold PBS and lysed in RIPA lysis buffer (WB3100, NCM Biotech)

Table 1. Primers for qRT-PCR.

\begin{tabular}{lll}
\hline GADD45 $\boldsymbol{\beta}$ & F: CGCCTGGCGCAGCTCCT, & R: AGCGTTCCTGAAGAGAGATG \\
c-Fos & F: TGCCTCTCCTCAATGACCCTGA, & R: ATAGGTCCATGTCTGGCACGGA \\
$\boldsymbol{\beta}$-actin & F: AGTGTGACGTGGACATCCGCA, & R: ATCCACATCTGCTGGAAGGTG GAC \\
c-jun & F: AGCTGGAGCGCCTGATAATC, & R:CTCCTGCTCATCTGTCACGTTCT \\
HSPA6 & F: GATGGTCGGTTCTCTCCATTG, & R: CTTCCATGAAGTGGTTCACGA \\
PPM1A & F: AGGGGCAGGGTAATGGGTT, & R: GATCACAGCCGTATGTGCATC \\
\hline
\end{tabular}


supplemented with protease inhibitors and phosphatase inhibitors for 30 mins on ice followed by centrifugation at $12,000 \mathrm{~g}$ for $15 \mathrm{~min}$ and supernatants were collected. The protein concentration was quantified by the BCA Protein Assay Kit (23227, Thermo Scientific). Proteins $(10 \mu \mathrm{g})$ per lane were resolved by SDS-PAGE and transferred to NC membrane (GE Healthcare Life Sciences). Non-specific binding sites were blocked using $1 \times$ TBS containing $0.05 \%$ (v/v) Tween 20 and 5\% (w/v) skimmed milk for $1 \mathrm{~h}$ at room temperature (RT). After washing, the membranes were incubated with the indicated primary antibody HSPA6 (A7688, 1:1000) and c-FOS (A16641, 1:1000) from ABclonal, PARP (\#9532, 1:1000 Cell Signaling Technology), $\beta$-actin (HC201, 1:1000, TransGen Biotech) overnight at $4^{\circ} \mathrm{C}$, washed and further incubated with an appropriate horseradish peroxidase-conjugated secondary antibody (1:5000, Sangon
Biotech) at RT for $1 \mathrm{~h}$. Visualization of reactive protein bands was performed using ChemiScope 6000 Touch (Clinx).

Statistical analysis. Prism 8.0 software was used for statistical analysis. The values were presented as the mean \pm SD . Statistical analyses were performed using Student's t-test. The analysis of multiple groups was performed with one or two-way ANOVA with an appropriate post-hoc test.

\section{Results}

Metformin pre-treatment enhances the inhibitory effects of CAP to glioma cells. To explore the inhibitory effects of CAP or Met on tumor cells, glioma cell lines U251, U87 were exposed to CAP for variable time (10, 20, 40, 60 s) or concentrations $(2,4,8$, and $16 \mathrm{mM})$ of Met for $24 \mathrm{~h}$ or $48 \mathrm{~h}$, respectively. U251/U87 cells were plated in 96 well, the cell
A
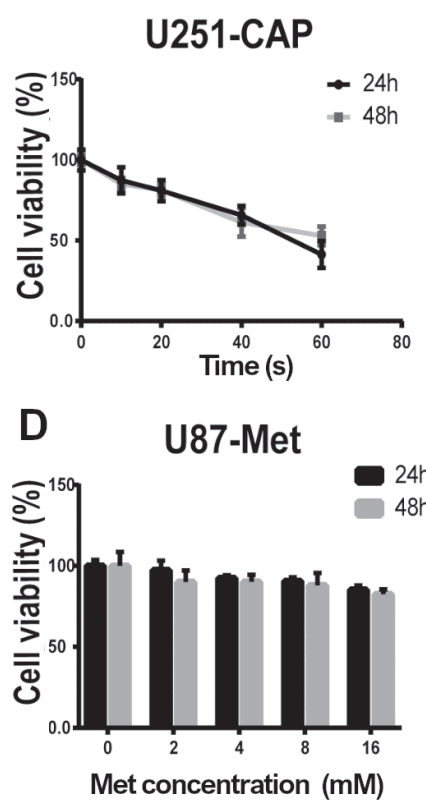

G

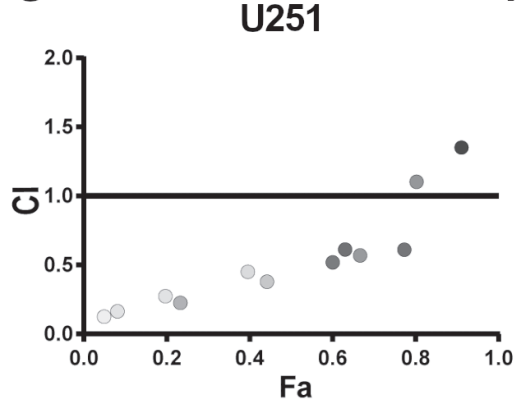

B

U87-CAP
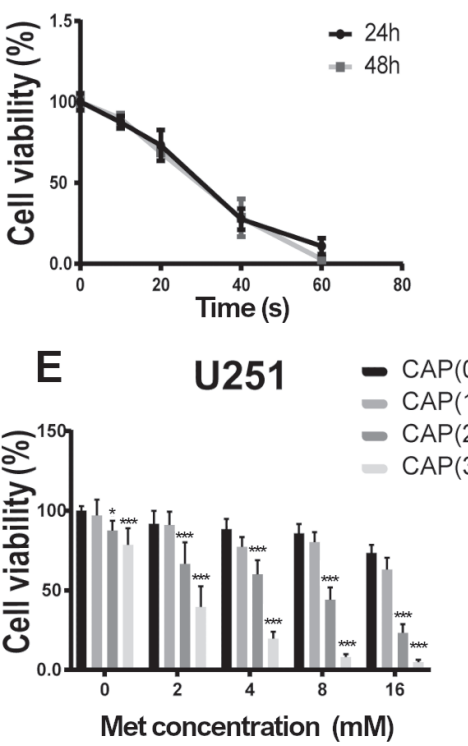

H
C
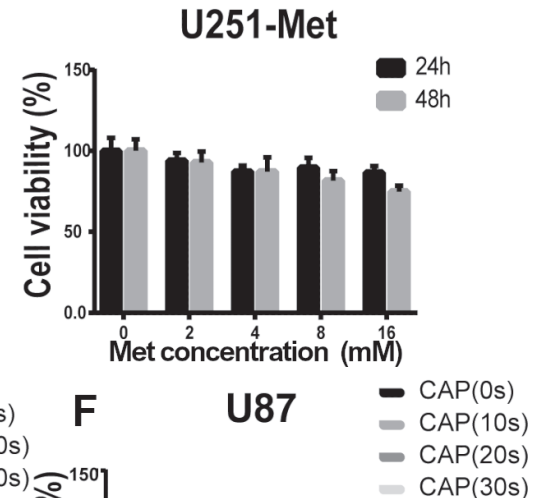

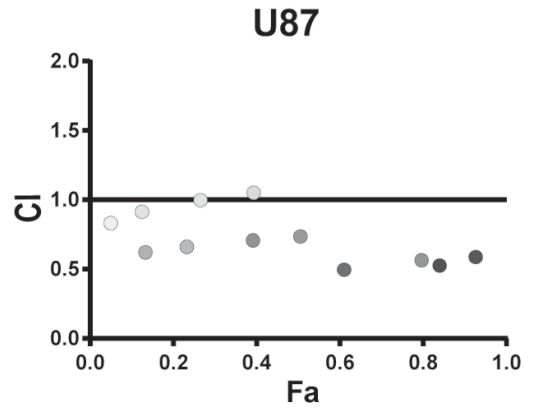

10s CAP+2mM Met $10 \mathrm{~s}$ CAP+4mM Met 10 CAP+8mM Met 10s CAP+16mM Met

20s CAP+2mM Met 20s CAP+4mM Met 20 s CAP+8mM Met 020 s CAP+16mM Met - 30s CAP+2mM Met 30s CAP+4mM Met 30s CAP+8mM Met 30 s CAP+16mM Met

Figure 1. Inhibition of cell viability by metformin, CAP only, or combination. A, B) CAP inhibited Cell viability in a dose-dependent way, C, D) Cell viability of two glioma cell lines upon $24 \mathrm{~h}$ or $48 \mathrm{~h}$ treatment with metformin $(0,2,4,8$, and $16 \mathrm{mM})$ or CAP exposure (0, 10, 20, 40, and 60 s). E, F) The viability of cells treated with metformin combine with CAP. Pretreated glioma cells with metformin $(0,2,4,8$, and 16 mM) for 12 h followed by exposure to CAP $(0,10,20$, and $30 \mathrm{~s})$, Cell viability was measured at 12 hours after CAP treatment. G, H) Synergy was analyzed by CompuSyn software. U251/U87 cells were plated in 96 well, the cell density of U251 was $1 \times 10^{4}$, U87 was $0.5 \times 10^{4}$. The value CI $<1$ means synergy. The data represented as the mean \pm SD from 3 independent experiments. ${ }^{*} \mathrm{p} \leq 0.05 ;{ }^{* *} \mathrm{p} \leq 0.001$; CAP - cold atmospheric plasma; Met - metformin 
density of U251 was $1 \times 10^{4} /$ well, U87 was $0.5 \times 10^{4} /$ well. Using the Cell Titer-Blue Cell viability assay, the effect of different CAP exposures and Met dose on glioma cell viability was investigated. For the CAP treatment, an exposure timedependent but not the incubation time-dependent reduction in viability was observed in both cell lines. Moreover, CAP has a more obvious inhibitory effect on U87 compared to U251 (Figures 1A, 1B). For the Met treatment, Met has a weak toxic effect on both cell lines in a dose-dependent manner and irrespective of exposure time (Figures 1C, 1D). Based on current observations and previous reports that Met could sensitize tumor cells to multiple chemotherapeutic drugs $[16,18,19]$, we tried to ask whether Met could sensitize glioma cells to CAP. Therefore, glioma cells were pre-treated with Met for $12 \mathrm{~h}$ and then exposed to CAP for specific timelines $(10,20$, and $30 \mathrm{~s})$. Figure 2 shows the effect of the combination on normal cells and the relationship between the cell density and the effect of the combination. Mouse primary astrocyte cells at a density of $1 \times 10^{4}$ were selected as the nonmalignant control group (Figure 2A). Although a combination of Met and CAP suppressed the astrocyte cells viability, the extent of inhibition was lower than the effect on U251 and U87 (Figures 2B, 2C) especially in the low concentration of Met ( 2 and $4 \mathrm{mM})$ and $30 \mathrm{~s}$ CAP.
U251/U87 glioma cell lines were chosen for study at different densities. At the cell density of $1.5 \times 10^{4}$, the inhibitory effect of the combination was weakly decreased compared with CAP or Met treatment alone on both cell lines. At the U251 cell density of $0.5 \times 10^{4}$ (Figure $2 \mathrm{~B}$, left panel), the inhibitory effect of the combination was weakly decreased compared with CAP alone. Conversely, at the U251 cell density of $1 \times 10^{4}$ (Figure 1E), U87 cell density of $0.5 \times 10^{4}$ (Figure $1 \mathrm{~F}$ ), a combination showed a more obvious inhibitory effect compared to CAP or Met alone, respectively. These results illustrated that the combination effect depended on the density of the cells. Further analysis demonstrated a synergistic effect of Met and CAP in the combination treatment (Figures 1G, 1H). These findings demonstrate that CAP leads to synergistic or additive toxicity in glioma cells sensitized with Met.

Combined treatment significantly induces glioma cell apoptosis. Met treatment alone had no effect on cell morphology, while cell antennae were recovered after CAP treatment in U251, U87 cells (Figures 3A, 3B, third panel, arrows). This also confirms previous studies that CAP can inhibit cell migration and promote cell detachment [7, 23]. However, combination Met and CAP can significantly change cell morphology, producing a death-like phenotype (Figures 3A, 3B, fourth panel). Apoptosis was tested by flow
A

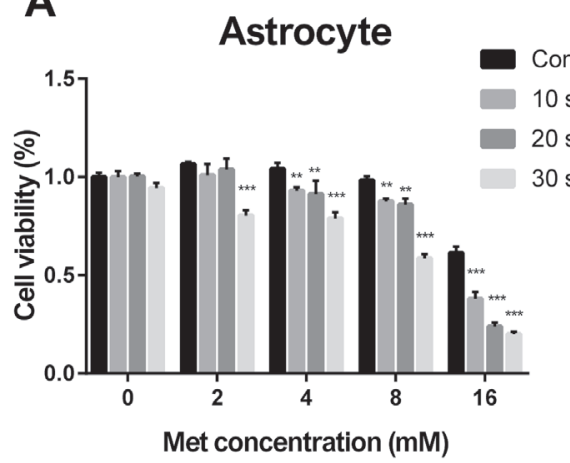

B

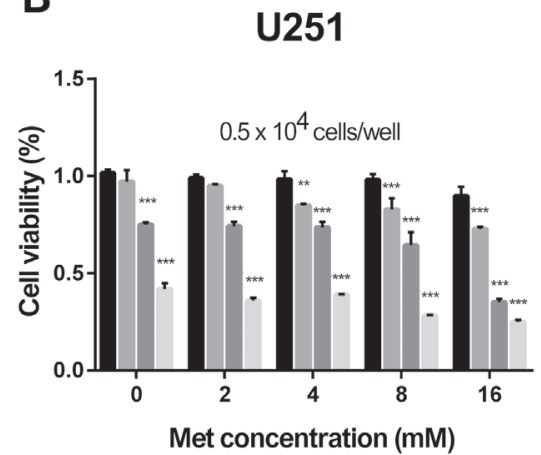

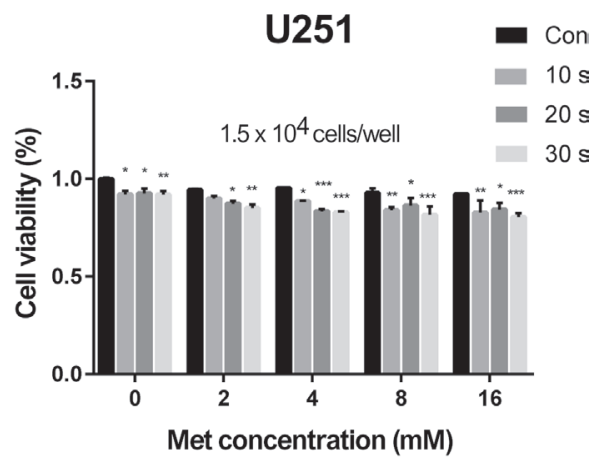

C
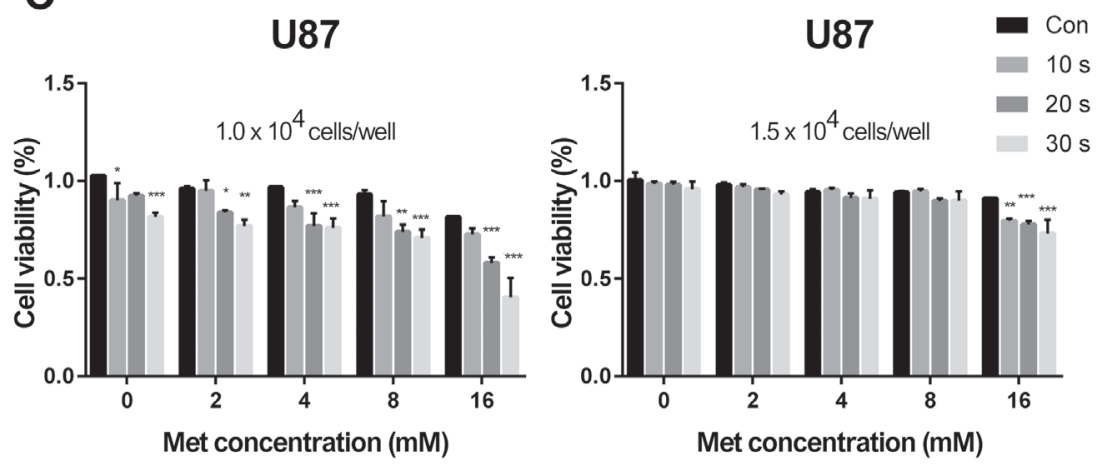

Figure 2. The effect of a combination on normal cells and the relationship between the cell density and the effect of a combination. A) The combination effect on mouse primary astrocyte cells in the cell density of $1 \times 10^{4}$, cell viability was tested by CellTiter Blue kits. The combination effect on different cell density of U251 (B) and U87 (C). ${ }^{*} \mathrm{p}<0.05 ;{ }^{* *} \mathrm{p}<0.01 ;{ }^{* *} \mathrm{p}<0.001$ 
A

U251
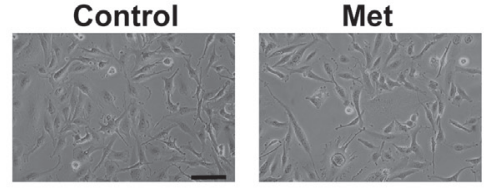

B U87

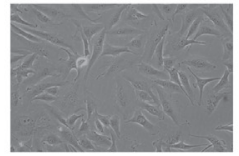

C

U251

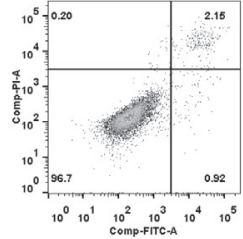

D

U87

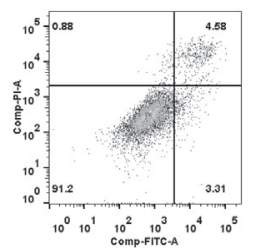

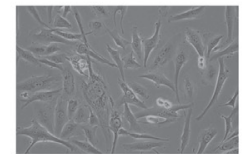
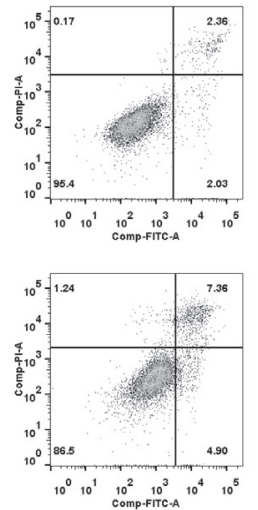
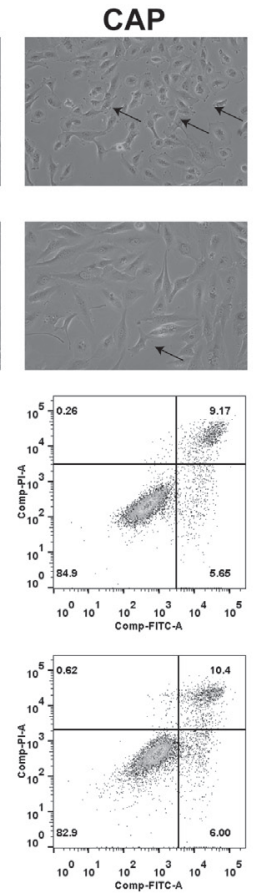
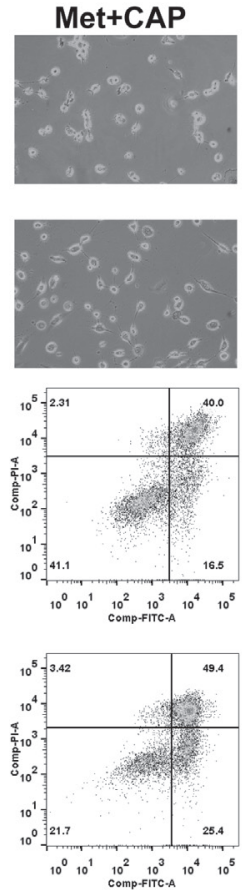

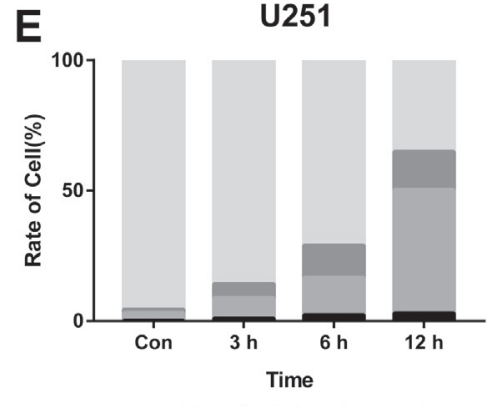

Live cell Early apoptosis

- Necrosis Late apoptosis

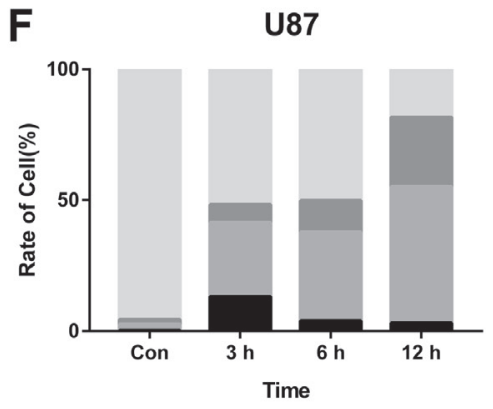

Figure 3. A combination significantly induced cell apoptosis. A, B) Brightfield view of glioma cells pretreated with metformin (16 mM) for $12 \mathrm{~h}$ followed by exposure to CAP (30 s). A black arrow represents recovered cell antennae. C, D) Cell apoptosis was detected by flow cytometry. E, F) Apoptosis kinetics of the combination group. U251/U87 cells were plated in 24 -well plate, the cell density of U251 was $5 \times 10^{4}$, U87 was $2.5 \times 10^{4}$. The data represented as the mean \pm SD from 3 independent experiments. Scale bar $=100 \mu \mathrm{m}$.

A

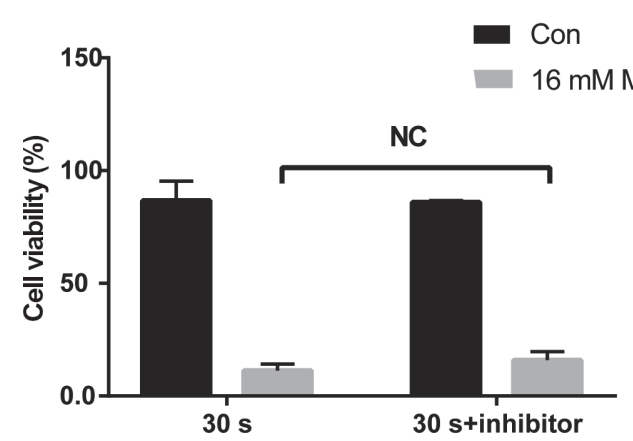

B

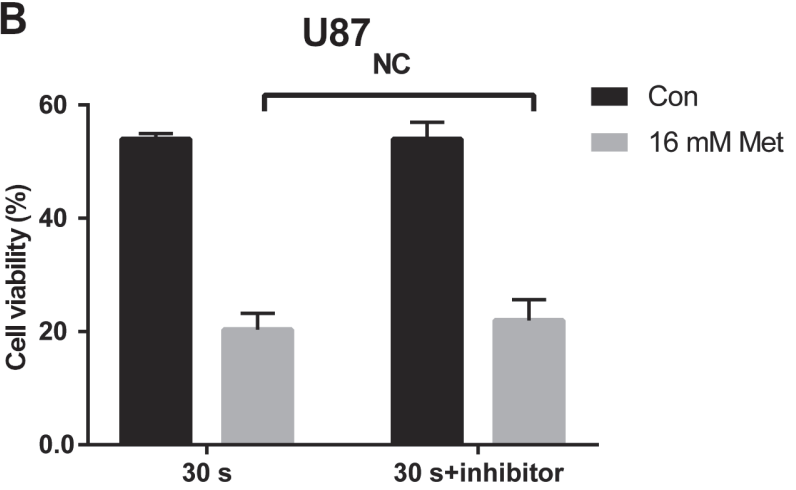

Figure 4. The effect of total caspase inhibitor on the combination group. U251 (A) at the cell density of $\left.1 \times 10^{4}\right)$ and U87 cell (B) at the cell density of $0.5 \times 10^{4}$ were pretreated with Met for $12 \mathrm{~h}$, then the cell-permeable pan caspase inhibitor Z-VAD-FMK (40 $\mu$ M) was added to the culture medium $1 \mathrm{~h}$ before CAP treatment. Cell viability was tested at $12 \mathrm{~h}$ after CAP treatment.

cytometry analysis. A combination significantly induced cell apoptosis (FITC stain, Figures 3C, 3D). Apoptosis kinetics showed that after CAP treatment, the apoptosis rate of the combination group increased with the incubation time (Figures 3E, 3F). It seems that Met enhanced the vulnerability of glioma cells to CAP, and CAP induced cell death through the apoptosis pathway. Pretreated U251 (at the cell density of $1 \times 10^{4}$ ) and U87 cells (at the cell density of $0.5 \times 10^{4}$ ) with Met for $12 \mathrm{~h}$, the cell permeable pan caspase inhibitor (Z-VAD-FMK, $40 \mu \mathrm{M}$ ) was added to the culture medium 1 hour before CAP treatment and cell viability was not reversed after caspase inhibitor was added. This result demonstrates that combination-induced cell apoptosis may not through the caspase pathway.

$\mathrm{H}_{2} \mathrm{O}_{2}$ plays an important role in the synergistic effect. Previous studies have shown that CAP can increase the intracellular ROS and the concentration of hydrogen peroxide in the medium $[24,25]$. To test whether it also has the same effect in this study, we measured intracellular ROS through the fluorescent probe DCFH-DA. Indeed, CAP significantly 
increased the intracellular ROS level in both cell lines (Figure $5 \mathrm{~A})$. Next, we measured the hydrogen peroxide concentration in the medium. The concentration of hydrogen peroxide was also found to be remarkably increased (Figure 5B). Based on changes in intracellular ROS level and hydrogen peroxide concentration in the medium, we proposed that hydrogen peroxide may have a role in the synergistic effect of Met and CAP. Therefore, we added catalase directly to the medium in the presence or absence of Met before CAP treatment. No wonder, after the addition of catalase the toxic effect of the combination was completely reversed and no change in cell morphology was observed (Figures 5C-5F). In addition, a similar synergistic killing effect was observed when the hydrogen peroxide was directly added after tumor cells were pretreated by Met (Figures 5C-5F). However, this phenomenon was not observed with hydrogen peroxide treatment alone. These findings indicate that CAP synergistically kills glioma cells through the production of hydrogen peroxide.

The combination of CAP and Met increases the expression of c-fos. Previous studies reported that the upregulation of c-fos, c-jun, GADD45A, HSPA6, and PPM1A had been constantly found in Met treated colorectal cancer [20]. Therefore, we also examined the expression of these genes in this study. A dramatic upregulation of HSPA6 was found in combination-treated U251 and U87 cells and a slight upregulation of GADD45A in U87 cells. Interestingly, combination therapy significantly increased the expression of c-fos in U251, U87 cells (Figures 6A, 6B). Next, we performed western blot to identify the changes in the expression of respective genes at the protein level. Although CAP only and combination therapy markedly increased HSPA6 mRNA, it had a little effect at the protein level in both cell lines. Consistently, the combination can increase the expression of c-fos at both mRNA and the protein level (Figure 6C). Moreover, after catalase was added to the combined group, the expression of c-fos was downregulated compared with the combined group. The combination of Met and hydrogen peroxide had a similar c-fos protein expression as the combination of Met and CAP (Figures 6D-6E). These findings further proved that hydrogen peroxide produced by CAP and Met has a synergistic killing effect.

\section{Discussion}

In the past decades, CAP has shown a broad-spectrum anti-tumor effect on different cancer types [6]. Although a low level of CAP can selectively kill tumor cells, high doses of CAP can also kill normal cells $[26,27]$. Recent publica-
A
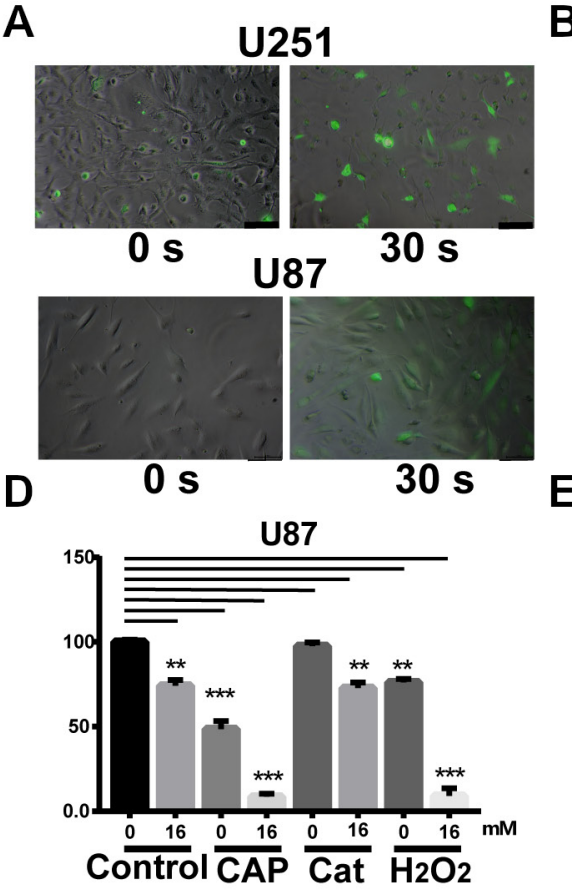

B
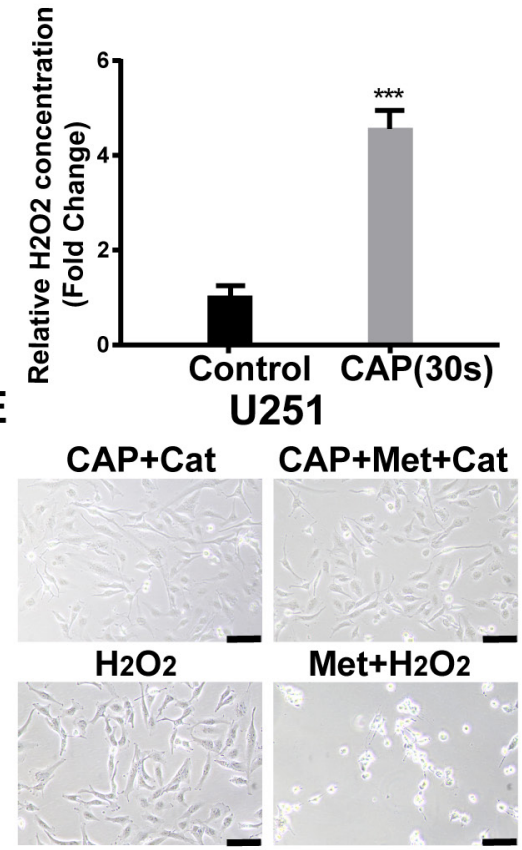

C
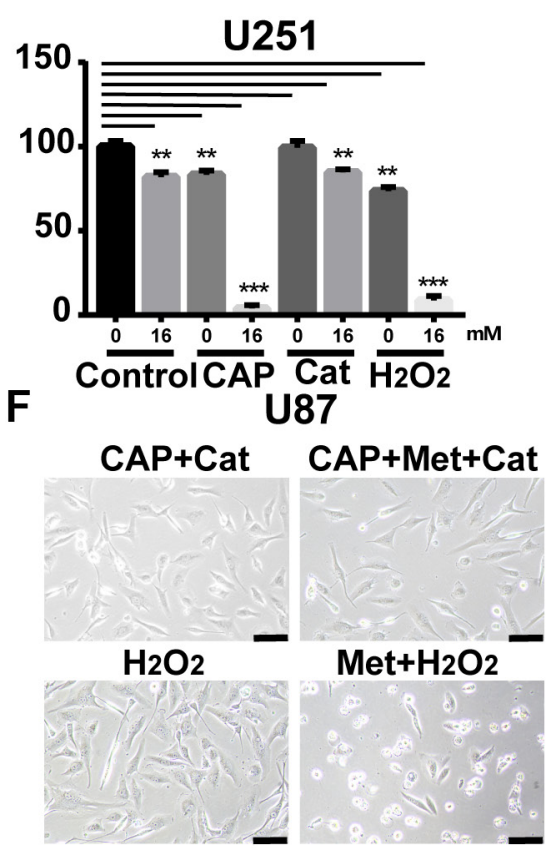

Figure 5. The role of ROS produced by CAP in synergistic inhibition effect. A) Intracellular ROS levels were measured after CAP treatment by the DCFH-DA probe (Left). B) Hydrogen peroxide was detected by Hydrogen Peroxide Assay Kit (Right). C, D) Glioma cells were pretreated with metfor$\min (16 \mathrm{mM})$ for $12 \mathrm{~h}$, and then catalase $(300 \mathrm{U})$ was added followed by exposure to CAP. Or pretreated with (16 mM) for $12 \mathrm{~h}$ followed by the addition of $\mathrm{H}_{2} \mathrm{O}_{2}(150 \mu \mathrm{M})$. Cell viability was measured at 12 hours after CAP or $\mathrm{H}_{2} \mathrm{O}_{2}$ treatment. E, F) The images of C-D under the brightfield microscope. U251/U87 cells were plated in 96 well-plate, the cell density of U251 was $1 \times 10^{4}$, U87 was $0.5 \times 10^{4}$. The data represented as the mean \pm SD from 3 independent experiments. ${ }^{* *} \mathrm{p}<0.01 ;{ }^{* *} \mathrm{p}<0.001$; Scale bar $=100 \mu \mathrm{m}$ 
A

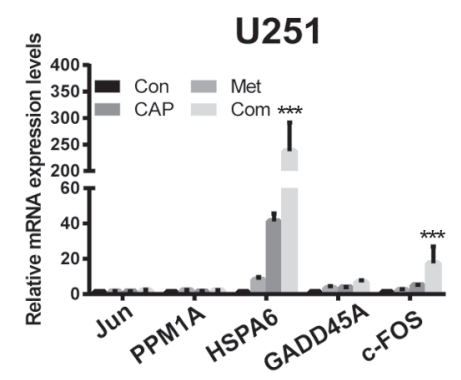

D

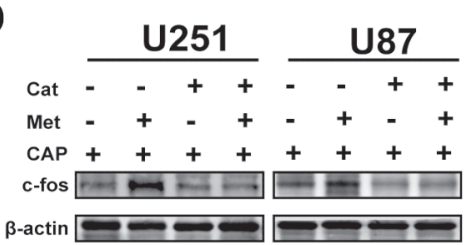

B

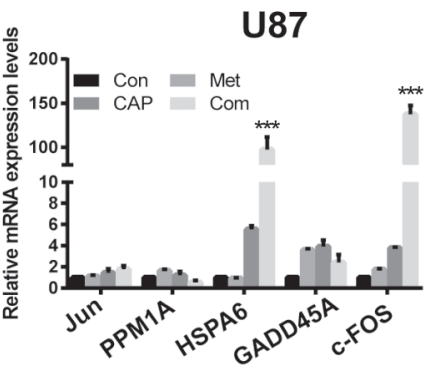

$E$

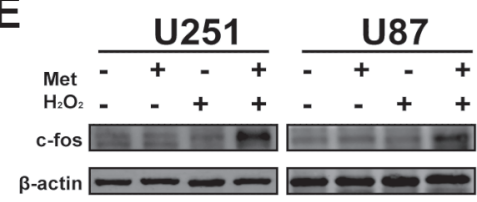

C

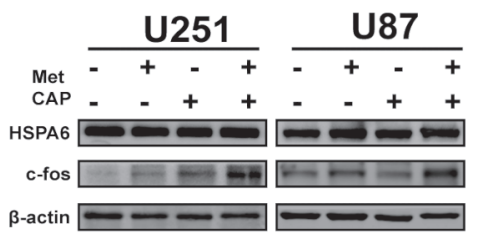

Figure 6. The expression of c-FOS was upregulated in cells treated with metformin and CAP increased the expression of c-FOS. A, B) The mRNA levels of Jun, PPM1A, HSPA6, GADD45A, and c-FOS were examined by the SYBR Green Realtime PCR Master Mix gene expression assay. $\beta$-actin was used as endogenous controls. C) Western blotting was performed to detect the protein expression of HSPA6 and c-FOS. D, E) Glioma cells were pretreated with metformin $(16 \mathrm{mM})$ for $12 \mathrm{~h}$, and then catalase $(300 \mathrm{U})$ was added followed by exposure to CAP. Or pretreated with metformin (16 mM) for 12 $h$ followed by the addition of $\mathrm{H}_{2} \mathrm{O}_{2}(150 \mu \mathrm{M})$. c-FOS expression was measured at 12 hours after $\mathrm{CAP}$ or $\mathrm{H}_{2} \mathrm{O}_{2}$ treatment. $\beta$-actin was used as an endogenous control. U251/U87 cells were plated in 24-well plate, the cell density of U251 was $5 \times 10^{4}$, U87 was $2.5 \times 10^{4}$. The data represented as the mean \pm SD from 3 independent experiments. ${ }^{* *} \mathrm{p} \leq 0.001$

tions have determined the window of selectivity of CAP action, this window is defined by the concentration of $\mathrm{H}_{2} \mathrm{O}_{2}$ in CAP $[28,29]$. There is accumulating evidence that CAP combined with chemical agents has a more delectable toxic effect compared with CAP or chemical agents alone $[8,12$, $13,30]$. In recent years, Met, the first-line drug for type 2 diabetes, has also exhibited a broad-spectrum anti-tumor effect [15]. Many studies showed that Met sensitizes tumor cells to chemotherapy drugs $[16,18,19]$. Based on these studies, we wonder whether the killing-effect of combined CAP with Met will be better than the CAP or Met only on tumor cells.

CAP changes cell membrane permeability or expression of certain transporters to facilitate the entry of drugs into cells [8]. Initial experiments were performed to determine the sequence of combination therapy in tumor cells. Preliminary results indicated that pre-treated glioma cells with CAP followed Met incubation for $24 \mathrm{~h}$ or co-treated with CAP and Met did not significantly decrease cell viability (data not shown). Inversely, pretreatment of the Met for $12 \mathrm{~h}$ robustly enhanced the sensitivity of tumor cells to CAP. A combination could significantly induce cell apoptosis. At least, those preliminary experiments showed that CAP did not increase the sensitivity of tumor cells to chemical drugs. Instead, pretreatment with Met changes the physiological state of the glioma cells, sensitizing cells to CAP.

In vitro, CAP does not directly contact with the cells due to the presence of a layer of medium between the cells and the CAP. CAP interacts with the culture medium to produce $\mathrm{H}_{2} \mathrm{O}_{2}, \mathrm{NO}, \mathrm{NO}_{2}^{-}$. Among diverse plasma-originated species, $\mathrm{H}_{2} \mathrm{O}_{2}$ has been proved as the main anti-cancer reactive species participate in CAP-induced cancer cells death in vitro $[7,9,24,30]$. But CAP-associated apoptosis was not directly induced by $\mathrm{H}_{2} \mathrm{O}_{2}$, it has been shown to be involved in at least three steps during CAP and PAM action. See references for more details [28, 29, 31, 32]. Consistent with these studies, the concentration of $\mathrm{H}_{2} \mathrm{O}_{2}$ in the culture medium significantly increased after CAP exposure in this study. At the same time, the intracellular ROS levels also raised after treatment of CAP (Figure 3), DCFH-DA-based fluorescence was not always reflecting the generation of ROS but may be related to heme or cytochrome c content in cells [33-35]. The real ROS levels may be detected by DCFA-based ROS test kits using cell-permeable inhibitors/ scavengers of DCFH-DA competitor. Next, we examined the role of hydrogen peroxide in a synergistic killing-effect. After catalase was added, the combination effect was totally reversed. Meanwhile, pre-treatment with Met and then supply with $\mathrm{H}_{2} \mathrm{O}_{2}$ had a similar synergistic killing effect with a combination of Met and CAP. Bauer et al. suggested that $\mathrm{H}_{2} \mathrm{O}_{2}$ and nitrite, two long-lived molecular species from CAP, triggers tumor cells to induce their own cell death [28]. We speculated that the synergistic killing-effect in our study was due to Met providing ROS or RNS to CAP, enhancing the CAP-associated cell death. Although Met has been reported as an antioxidant regent in diabetic patients [36], there was research suggested Met increased intracellular $\mathrm{ROS}$ [37]. The radical $\left(\mathrm{OH}\right.$ or $\left.\mathrm{O}_{2}^{-}\right)$-induced oxidation 
byproducts of metformin did not contain ROS and RNS [38], this means that the interaction between CAP and Met may not contribute to the synergistically inhibitory effect. In freshly isolated mouse hepatocytes, Met treatment increased $\mathrm{ONOO}^{-}$production [39]. The Met-pretreated U251/U87 cells may produce $\mathrm{ONOO}^{-}$, this species involved in CAP-associated cell death.

In the previous study, Met suppressed the proliferation of colon cancer cells and induced a time-dependent metabolic and transcriptional alteration [20]. We looked for the changes in the expression of genes reported previously. However, those genes (JUN, PPM1A, HSPA6, GADD45A, and c-FOS) were not significantly increased at the transcription level after the treatment of Met in this study. Interestingly, the c-FOS transcript and the protein levels were significantly upregulated after a combination of Met and CAP. c-FOS has been reported to regulate retinal neuronal cell death and Brazilin induced T24 cell death [40, 41]. Therefore, the role of c-FOS in this study needs to be explored further. Meanwhile, experiments also need to be performed to determine the effect of the combination of metformin and CAP in vivo. Because of the limitation of penetration depth, CAP was difficult to apply to solid tumors in vivo. Keidar et al. has developed a micro-CAP device that allows CAP to treat glioma in the mouse brain [10]. Miniaturization of CAP devices and implantable CAP devices may be a development direction for the treatment of brain tumors in the future.

In general, this study may provide a new method for gliomas therapy, but more substantial mechanisms need to be explored.

Acknowledgments: This work was supported by the Young Scientists Fund of the National Natural Science Foundation of China (81903028), the Jiangsu Province Natural Science Foundation for Youths (BK20180223), and a grant from Suzhou Institute of Biomedical Engineering and Technology, Chinese Academy of Sciences (SIBET) for animal experiments.

\section{References}

[1] DELGADO-LOPEZ PD, CORRALES-GARCIA EM. Survival in glioblastoma: a review on the impact of treatment modalities. Clin Transl Oncol 2016; 18: 1062-1071. https:// doi.org/10.1007/s12094-016-1497-x

[2] CHANG L, SU J, JIA X, REN H. Treating malignant glioma in Chinese patients: update on temozolomide. Onco Targets Ther 2014; 7: 235-244. https://doi.org/10.2147/OTT.S41336

[3] LAPOINTE S, PERRY A, BUTOWSKI NA. Primary brain tumours in adults. Lancet 2018; 392: 432-446. https://doi. org/10.1016/S0140-6736(18)30990-5

[4] RAJESH Y, PAL I, BANIK P, CHAKRABORTY S, BORKAR SA et al. Insights into molecular therapy of glioma: current challenges and next generation blueprint. Acta Pharmacol Sin 2017; 38: 591-613. https://doi.org/10.1038/aps.2016.167
[5] COHEN KJ, POLLACK IF, ZHOU T, BUXTON A, HOLMES EJ et al. Temozolomide in the treatment of high-grade gliomas in children: a report from the Children's Oncology Group. Neuro Oncol 2011; 13: 317-323. https://doi. org/10.1093/neuonc/noq191

[6] DAI X, BAZAKA K, RICHARD DJ, THOMPSON ERW, OSTRIKOV KK. The Emerging Role of Gas Plasma in Oncotherapy. Trends Biotechnol 2018; 36: 1183-1198. https:// doi.org/10.1016/j.tibtech.2018.06.010

[7] XIANG L, XU X, ZHANG S, CAI D, DAI X. Cold atmospheric plasma conveys selectivity on triple negative breast cancer cells both in vitro and in vivo. Free Radic Biol Med 2018; 124: 205-213. https://doi.org/10.1016/j.freeradbiomed.2018.06.001

[8] SAGWAL SK, PASQUAL-MELO G, BODNAR Y, GANDHIRAJAN RK, BEKESCHUS S. Combination of chemotherapy and physical plasma elicits melanoma cell death via upregulation of SLC22A16. Cell Death Dis 2018; 9: 1179. https:// doi.org/10.1038/s41419-018-1221-6

[9] GJIKA E, PAL-GHOSH S, TANG A, KIRSCHNER M, TADVALKAR $G$ et al. Adaptation of Operational Parameters of Cold Atmospheric Plasma for in Vitro Treatment of Cancer Cells. ACS Appl Mater Interfaces 2018; 10: 9269-9279. https://doi.org/10.1021/acsami.7b18653

[10] CHEN Z, SIMONYAN H, CHENG X, GJIKA E, LIN L et al. A Novel Micro Cold Atmospheric Plasma Device for Glioblastoma Both In Vitro and In Vivo. Cancers (Basel) 2017; 9. https://doi.org/10.3390/cancers9060061

[11] BEKESCHUS S, LIPPERT M, DIEPOLD K, CHIOSIS G, SEUFFERLEIN T et al. Physical plasma-triggered ROS induces tumor cell death upon cleavage of HSP90 chaperone. Sci Rep 2019; 9: 4112. https://doi.org/10.1038/s41598-01938580-0

[12] ADACHI T, KANO A, NONOMURA S, KAMIYA T, HARA $\mathrm{H}$. Histone deacetylase inhibitors stimulate the susceptibility of A549 cells to a plasma-activated medium treatment. Arch Biochem Biophys 2016; 606: 120-127. https://doi. org/10.1016/j.abb.2016.07.019

[13] KORITZER J, BOXHAMMER V, SCHAFER A, SHIMIZU T, KLAMPFL TG et al. Restoration of sensitivity in chemo-resistant glioma cells by cold atmospheric plasma. PLoS One 2013; 8: e64498. https://doi.org/10.1371/journal. pone.0064498

[14] MORALES DR, MORRIS AD. metformin in cancer treatment and prevention. Annu Rev Med 2015; 66: 17-29. https://doi.org/10.1146/annurev-med-062613-093128

[15] VANCURA A, BU P, BHAGWAT M, ZENG J, VANCUROVA I. metformin as an Anticancer Agent. Trends Pharmacol Sci 2018; 39: 867-878. https://doi.org/10.1016/j. tips.2018.07.006

[16] LEE JE, LIM JH, HONG YK, YANG SH. High-Dose metformin Plus Temozolomide Shows Increased Anti-tumor Effects in Glioblastoma In Vitro and In Vivo Compared with Monotherapy. Cancer Res Treat 2018; 50: 1331-1342. https:// doi.org/10.4143/crt.2017.466

[17] KOLESNIK DL, PYASKOVSKAYA ON, YURCHENKO OV, SOLYANIK GI. metformin enhances antitumor action of sodium dichloroacetate against glioma C6. Experimental Oncology 2019; 41: 123-129. https://doi.org/10.32471/exponcology.2312-8852.vol-41-no-2.13064 
[18] LING S, SONG L, FAN N, FENG T, LIU L et al. Combination of metformin and sorafenib suppresses proliferation and induces autophagy of hepatocellular carcinoma via targeting the mTOR pathway. Int J Oncol 2017; 50: 297-309. https:// doi.org/10.3892/ijo.2016.3799

[19] YU C, JIAO Y, XUE J, ZHANG Q, YANG H et al. metformin Sensitizes Non-small Cell Lung Cancer Cells to an Epigallocatechin-3-Gallate (EGCG) Treatment by Suppressing the Nrf2/HO-1 Signaling Pathway. Int J Biol Sci 2017; 13: 1560 1569. https://doi.org/10.7150/ijbs. 18830

[20] HE J, WANG K, ZHENG N, QIU Y, XIE G et al. metformin suppressed the proliferation of LoVo cells and induced a time-dependent metabolic and transcriptional alteration. Sci Rep 2015; 5: 17423. https://doi.org/10.1038/srep17423

[21] YAMANA H, KATO K, KOBARA H, FUJIHARA S, FUJITA $\mathrm{K}$ et al. metformin Inhibits Proliferation and Tumor Growth of QGP-1 Pancreatic Neuroendocrine Tumor Cells by Inducing Cell Cycle Arrest and Apoptosis. Anticancer Res 2020; 40: 121-132. https://doi.org/10.21873/anticanres.13933

[22] YAMASHITA T, KATO K, FUJIHARA S, IWAMA $\mathrm{H}$, MORISHITA A et al. Anti-diabetic drug metformin inhibits cell proliferation and tumor growth in gallbladder cancer via G0/G1 cell cycle arrest. Anticancer Drugs 2020; 31: 231-240. https://doi.org/10.1097/CAD.0000000000000870

[23] XU D, LUO X, XU Y, CUI Q, YANG Y et al. The effects of cold atmospheric plasma on cell adhesion, differentiation, migration, apoptosis and drug sensitivity of multiple myeloma. Biochem Biophys Res Commun 2016; 473: 1125-1132. https://doi.org/10.1016/j.bbrc.2016.04.027

[24] TURRINI E, LAURITA R, STANCAMPIANO A, CATANZARO E, CALCABRINI C et al. Cold Atmospheric Plasma Induces Apoptosis and Oxidative Stress Pathway Regulation in T-Lymphoblastoid Leukemia Cells. Oxid Med Cell Longev 2017; 2017: 4271065. https://doi.org/10.1155/2017/4271065

[25] LIEDTKE KR, BEKESCHUS S, KAEDING A, HACKBARTH C, KUEHN JP et al. Non-thermal plasma-treated solution demonstrates antitumor activity against pancreatic cancer cells in vitro and in vivo. Sci Rep 2017; 7: 8319. https://doi.org/10.1038/s41598-017-08560-3

[26] KEIDAR M, WALK R, SHASHURIN A, SRINIVASAN P, SANDLER A et al. Cold plasma selectivity and the possibility of a paradigm shift in cancer therapy. Br J Cancer 2011; 105: 1295-1301. https://doi.org/10.1038/bjc.2011.386

[27] HASSE S, DUONG TRAN T, HAHN O, KINDLER S, METELMANN HR et al. Induction of proliferation of basal epidermal keratinocytes by cold atmospheric-pressure plasma. Clin Exp Dermatol 2016; 41: 202-209. https://doi. org/10.1111/ced.12735

[28] BAUER G. The synergistic effect between hydrogen peroxide and nitrite, two long-lived molecular species from cold atmospheric plasma, triggers tumor cells to induce their own cell death. Redox Biol 2019; 26: 101291. https://doi. org/10.1016/j.redox.2019.101291

[29] BAUER G, SERSENOVA D, GRAVES DB, MACHALA Z. Cold Atmospheric Plasma and Plasma-Activated Medium Trigger RONS-Based Tumor Cell Apoptosis. Sci Rep 2019; 9: 14210. https://doi.org/10.1038/s41598-019-50291-0
[30] CONWAY GE, CASEY A, MILOSAVLJEVIC V, LIU Y, HOWE $\mathrm{O}$ et al. Non-thermal atmospheric plasma induces ROS-independent cell death in U373MG glioma cells and augments the cytotoxicity of temozolomide. Br J Cancer 2016; 114: 435-443. https://doi.org/10.1038/bjc.2016.12

[31] BAUER G, SERSENOVA D, GRAVES DB, MACHALA Z. Dynamics of Singlet Oxygen-Triggered, RONS-Based Apoptosis Induction after Treatment of Tumor Cells with Cold Atmospheric Plasma or Plasma-Activated Medium. Sci Rep 2019; 9: 13931. https://doi.org/10.1038/s41598-019-50329-3

[32] BAUER G. Intercellular singlet oxygen-mediated bystander signaling triggered by long-lived species of cold atmospheric plasma and plasma-activated medium. Redox Biol 2019; 26: 101301. https://doi.org/10.1016/j.redox.2019.101301

[33] BURKITT MJ, WARDMAN P. Cytochrome $\mathrm{c}$ is a potent catalyst of dichlorofluorescin oxidation: Implications for the role of reactive oxygen species in apoptosis. Biochem Bioph Res Commun 2001; 282: 329-333. https://doi.org/10.1006/ bbrc. 2001.4578

[34] OHASHI T, MIZUTANI A, MURAKAMI A, KOJO S, ISHII $\mathrm{T}$ et al. Rapid oxidation of dichlorodihydrofluorescin with heme and hemoproteins: formation of the fluorescein is independent of the generation of reactive oxygen species. FEBS Lett 2002; 511: 21-27. https://doi.org/10.1016/s00145793(01)03262-8

[35] WARDMAN P. Fluorescent and luminescent probes for measurement of oxidative and nitrosative species in cells and tissues: progress, pitfalls, and prospects. Free Radic Biol Med 2007; 43: 995-1022. https://doi.org/10.1016/j.freeradbiomed.2007.06.026

[36] CHU NV, KONG AP, KIM DD, ARMSTRONG D, BAXI S et al. Differential effects of metformin and troglitazone on cardiovascular risk factors in patients with type 2 diabetes. Diabetes Care 2002; 25: 542-549. https://doi.org/10.2337/ diacare.25.3.542

[37] ZHAO Y, LUO Q, MO J, LI J, YE D et al. metformin in combination with JS-K inhibits growth of renal cell carcinoma cells via reactive oxygen species activation and inducing DNA breaks. J Cancer 2020; 11: 3701-3712. https://doi. org/10.7150/jca.36372

[38] KHOURI H, COLLIN F, BONNEFONT-ROUSSELOT D, LEGRAND A, JORE D et al. Radical-induced oxidation of metformin. Eur J Biochem 2004; 271: 4745-4752. https://doi. org/10.1111/j.1432-1033.2004.04438.x

[39] FUJITA Y, HOSOKAWA M, FUJIMOTO S, MUKAI E, ABUDUKADIER A et al. metformin suppresses hepatic gluconeogenesis and lowers fasting blood glucose levels through reactive nitrogen species in mice. Diabetologia 2010; 53: 1472-1481. https://doi.org/10.1007/s00125-010-1729-5

[40] OSHITARI T, YAMAMOTO S, ROY S. Increased expression of c-Fos, c-Jun and c-Jun N-terminal kinase associated with neuronal cell death in retinas of diabetic patients. Curr Eye Res 2014; 39: 527-531. https://doi.org/10.3109/02713683.20 13.833248

[41] ZHANG T, HE J, ZHANG S, WANG G, MA E et al. Brazilin induces T24 cell death through c-Fos and GADD45beta independently regulated genes and pathways. IUBMB Life 2018; 70: 1101-1110. https://doi.org/10.1002/iub.1921 